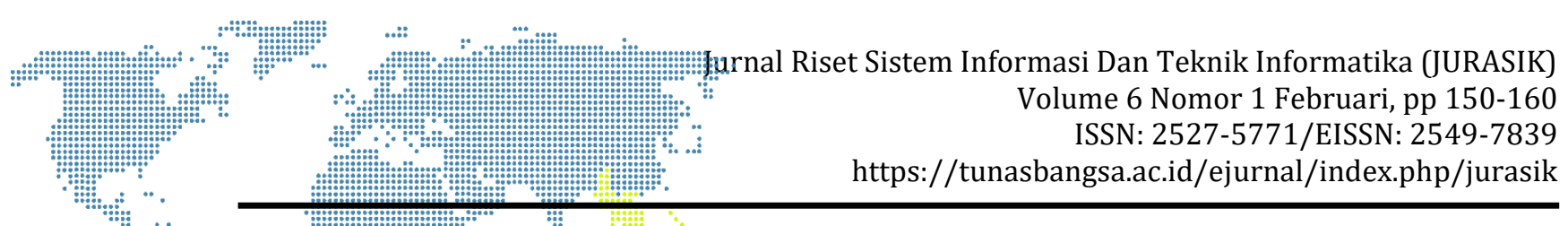

\title{
Metode Data Mining Klasifikasi Pada Kualitas Pelayanan Terhadap Nasabah Bank Syariah Mandiri dengan Model C4.5
}

\author{
Ari Supriadi1, Poningsih' ${ }^{2}$, Hendry Qurniawan ${ }^{3}$ \\ 1,3STIKOM Tunas Bangsa, Pematangsiantar, Sumatera Utara, Indonesia \\ ${ }^{2}$ AMIK Tunas Bangsa, Pematangsiantar, Sumatera Utara, Indonesia \\ Jln. Sudirman Blok A No. 1-3 Pematangsiantar, Sumatera Utara \\ 1ariesoepradi@gmail.com,²poningsih@amiktunasbangsa.ac.id,
}

\begin{abstract}
Customer satisfaction is the most important thing in assessing the level of management and services provided by the bank to its customers. The existence of banking services in society is indeed more profitable, especially in the economic sector, where economic actors are more free to carry out the process of economic activities to support survival. Data mining is an analysis of observations of large amounts of data to find relationships that are not known beforehand, data processed by the data mining method will produce a new knowledge sourced from old data, the results of processing can be used to determine future decisions. Using the C4.5 algorithm will predict which aspects are more dominant towards customer satisfaction. The data source of this research was collected based on a questionnaire (questionnaire) filled out by customers of Bank Syariah Mandiri in Pematangsiantar City. Data will be processed by calculating the value of entropy, calculating the gain value. So that the final results obtained in the form of a decision tree are expected to be input to the Bank Syariah Mandiri in Pematangsiantar City in maintaining the quality of its services to customers and improving the quality so that customers are always satisfied with the services provided.
\end{abstract}

Keywords: Customer Satisfaction, Data Mining, Algorithm C4.5

\section{Abstrak}

Kepuasan nasabah hal yang paling sangat penting dalam menilai tingkat manajemen dan pelayanan yang diberikan oleh bank kepada nasabahnya. Keberadaan jasa perbankan dalam masyarakat memang lebih menguntungkan terutama pada sektor perekonomian, di mana para pelaku ekonomi lebih leluasa dalam menjalankan proses kegiatan ekonominya untuk menunjang kelangsungan hidup. Data mining merupakan sebuah analisa dari observasi data dalam jumlah besar untuk menemukan hubungan yang tidak diketahui sebelumnya, data yang diolah dengan metode data mining akan menghasikan suatu pengetahuan baru yang bersumber dari data lama, hasil dari pengolahan dapat digunakan untuk menentukan keputusan di masa depan. Dengan menggunakan algoritma C4.5 akan memprediksi aspek mana yang lebih dominan terhadap kepuasan nasabah. Sumber data penelitian ini dikumpulkan berdasarkan kuesioner (angket) yang diisi oleh nasabah Bank Syariah Mandiri Kota Pematangsiantar. Data akan diolah dengan menghitung menentukan nilai entropy, menghitung nilai gain. Sehingga diperoleh hasil akhir berupa pohon keputusan yang diharapkan dapat menjadi masukan kepata pihak Bank Syariah Mandiri Kota Pematangsiantar dalam menjaga kualitas pelayanannya terhadap nasabah serta meningkatkan kualitas yang ada agar nasabah selalu merasa puas dengan pelayanan yang diberikan.

Kata kunci: Kepuasan Nasabah, Data Mining, Algoritma C4.5

\section{PENDAHULUAN}

Kepuasan nasabah merupakan salah satu hal yang sangat penting dalam menilai tingkat pelayanan yang diberikan oleh pihak Bank kepada setiap nasabahnya. Bank merupakan salah satu lembaga keuangan yang mempunyai peranan penting dalam perekononian pada suatu negara karena perkembangan 


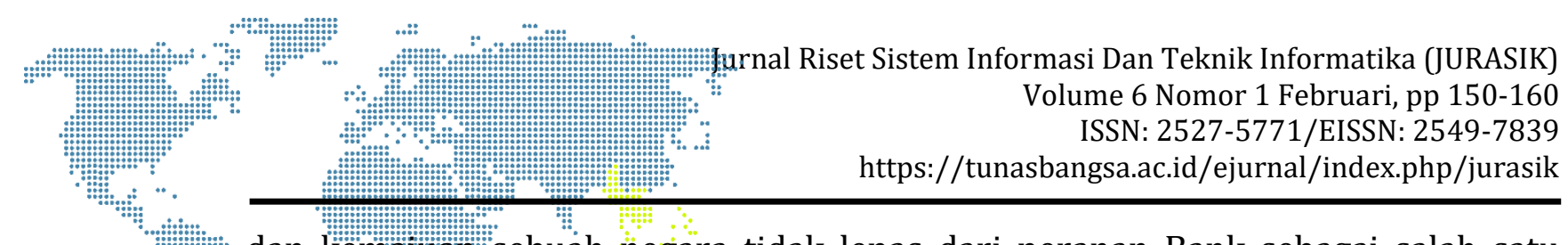

dan kemanuana"sebuah negara tidak lepas dari peranan Bank sebagai salah satu iembaga keungan.

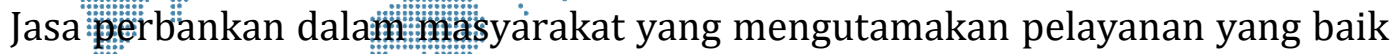
demi memperoleh kepercayaan dari masyarakat sebagai nasabahnya yang akan menghadapi berbagai macam keadaan atau pandangan yang timbul dari masyarakat sebagai ungkapan kepuasan atau ketidakpuasannya atas pelayanan yang diterimanya dari pihak Bank yang dipercayainya.

Sering kali terjadi ketidakseimbangan antara kinerja pihak bank dengan kesesuaian harapan setiap nasabah misalnya seperti dalam hal antrian, sering terjadi pada setiap nasabah mengeluh akan pelayanan yang dirasakan kurang cepat oleh pihak nasabah dan masih terdapat hal-hal yang memungkinkan terjadinya pelayanan Bank yang tidak sesuai oleh harapan nasabah.

Setiap Bank mempunyai standar pelayanannya masing-masing. Ada beberapa aspek yaitu Assurance (Jaminan), Tangible (Bukti Nyata), Responsiveness (Tanggapan). Algoritma C4.5 ini merupakan metode klasifikasi dan prediksi yang sangat terkenal. Metode pohon keputusan mengubah fakta yang sangat besar menjadi pohon keputusan yang mempresentasikan aturan. Salah satu Algoritma yang digunakan untuk melakukan klasifikasi atau segmentasi atau pengelompokan dan bersifat prediktif. Algoritma untuk membuktikan suatu pohon keputusan Decision Tree C4.5. Dengan melihat latar belakang diatas, penilitian ini diharapkan dapat membantu kualitas pelayanan terhadap nasabah dan sebagai evaluasi kinerja dan meningkatkan mutu kualitas pelayanan di Bank Syariah Mandiri agar menjadi lebih baik lagi.

\section{METODOLOGI PENELITIAN}

\subsection{Pengumpulan Data}

Penelitian ini dilakukan di Bank Syariah Mandiri yang terletak di Jl. Perintis Kemerdekaan No.1 Pematangsiantar. Dalam penelitian ini data yang diperoleh dari hasil observasi dan pembagian kuisoner kepada nasabah sebanyak 50 nasabah. Atribute Data yang digunakan terdiri dari :
a) Usia
Dengan menggunakan 3 Linked yaitu Remaja : $<20$ thn, Dewasa : $>20$ - 40, dan Tua : $>40$ thn
b) Pekerjaan Sesuai dengan pilihan reponden sendiri
c) Lama menjadi nasabah Dengan mengelompokkan menjadi 4 bagian, yaitu $<1$ Tahun = Baru, $>1-3$ Tahun $=$ Cukup lama , 3 Tahun $=$ Lama,$>3$ Tahun $=$ Sangat Lama
d) Assurance (Jaminan) Menggunakan 4 Linked yaitu, Sangat Baik, Baik, Cukup dan Kurang Baik
e) Tangible (Bukti nyata) Menggunakan 4 Linked yaitu, Sangat baik, Baik, Cukup dan Kurang Baik
f) Responsiveness (Ketanggapan) Menggunakan 4 Linked yaitu, Sangat baik, Baik, Cukup dan Kurang Baik 
https://tunasbangsa.ac.id/ejurnal/index.php/jurasik

Tabel 1. Hasil Rekapitulasi Kuisioner

\begin{tabular}{|c|c|c|c|c|c|c|c|}
\hline Alternatifit & 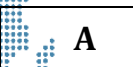 & : & C & D & $\mathbf{E}$ & $\mathbf{F}$ & Keterangan \\
\hline A1 & Dewasa & Pegawallswasta & $\mathrm{CL}$ & SB & SB & $\mathrm{C}$ & Puas \\
\hline A2 & Dewasa & Wiraswästa. & $\mathrm{BR}$ & $\mathrm{B}$ & $\mathrm{B}$ & B & Puas \\
\hline A3 & Dewasa & Pegawai Swasta & BR & SB & $\mathrm{B}$ & $\mathrm{C}$ & Puas \\
\hline A4 & Dewasa & Wiraswasta & $\mathrm{L}$ & SB & SB & SB & Puas \\
\hline A5 & Dewasa & Pegawai Swasta & BR & SB & SB & $\mathrm{B}$ & Puas \\
\hline A6 & Dewasa & Pegawai Swasta & $\mathrm{BR}$ & SB & SB & $\mathrm{B}$ & Puas \\
\hline A7 & Remaja & Pelajar & BR & SB & SB & SB & Puas \\
\hline A8 & Dewasa & Pegawai BUMN & CL & SB & $\mathrm{SB}$ & $\mathrm{B}$ & Puas \\
\hline A9 & Dewasa & Pegawai BUMN & $\mathrm{L}$ & SB & SB & SB & Puas \\
\hline A10 & Dewasa & Pegawai Swasta & BR & SB & $\mathrm{B}$ & $\mathrm{C}$ & Puas \\
\hline$\ldots$ & ... & $\ldots$ & $\ldots$ & $\ldots$ & $\ldots$ & $\ldots$ & $\cdots$ \\
\hline A50 & Tua & PNS & $\mathrm{L}$ & $\mathrm{B}$ & $\mathrm{B}$ & $\mathrm{B}$ & Puas \\
\hline
\end{tabular}

Keterangan :

A : Usia

B : Pekerjaaan

C : Lama menjadi nasabah ( $\mathrm{BR}=\mathrm{Baru}, \mathrm{CL}=$ Cukup lama , $\mathrm{L}=$ Lama )

D : Bukti nyata ( $\mathrm{SB}=$ Sangat baik , B = Baik , C = Cukup )

E : Jaminan ( SB = Sangat baik , B = Baik , C = Cukup )

F : Ketanggapan ( SB = Sangat baik , B = Baik , C = Cukup )

\subsection{Metode Penelitian}

\section{a. Pengertian Data Mining}

Data Mining merupakan proses menemukan sebuah kolerasi baru yang bermakna, dengan memilih sejumlah data yang tersimpan di dalam repositori, yang menggunakan teknologi penalaran pola serta teknik-teknik statistik dan matematika" [1]. "Data Mining didefenisikan sebagai sebuah proses untuk menemukan pola, hubungan dan trend yang sangat besar dengan cara menggunakan teknik pengenalan pola seperti teknik statistic dan matematika" [2].

\section{b. Algoritma C4.5}

Algoritma C4.5 ini sendiri merupakan pengembangan dari Algoritma ID3, pengembangan tersebut dilakukan dalam hal, mampu mengatasi sebuah missing data. Algoritma C4.5 merupakan metode yang paling sering digunakan untuk klasifikasi data yang mempunyai atribut atribut numerik dan kategorial" [3].

Algoritma C4.5 untuk membangun pohon keputusan adalah :

1) Pilih atribut sebagai pakar

2) Buat cabang untuk setiap nilai

3) Bagi kasus dalam cabang

4) Ulangi proses untuk setiap cabang sampai semua cabang mempunyai kelas yang sama

Untuk menjadikan atribut sebagai akar, berdasarkan pada nilai Gain tertinggi dari atribut-atribut yang ada. Untuk menghitung Gain menggunakan rumus seperti sebagai berikut [4][5]: 


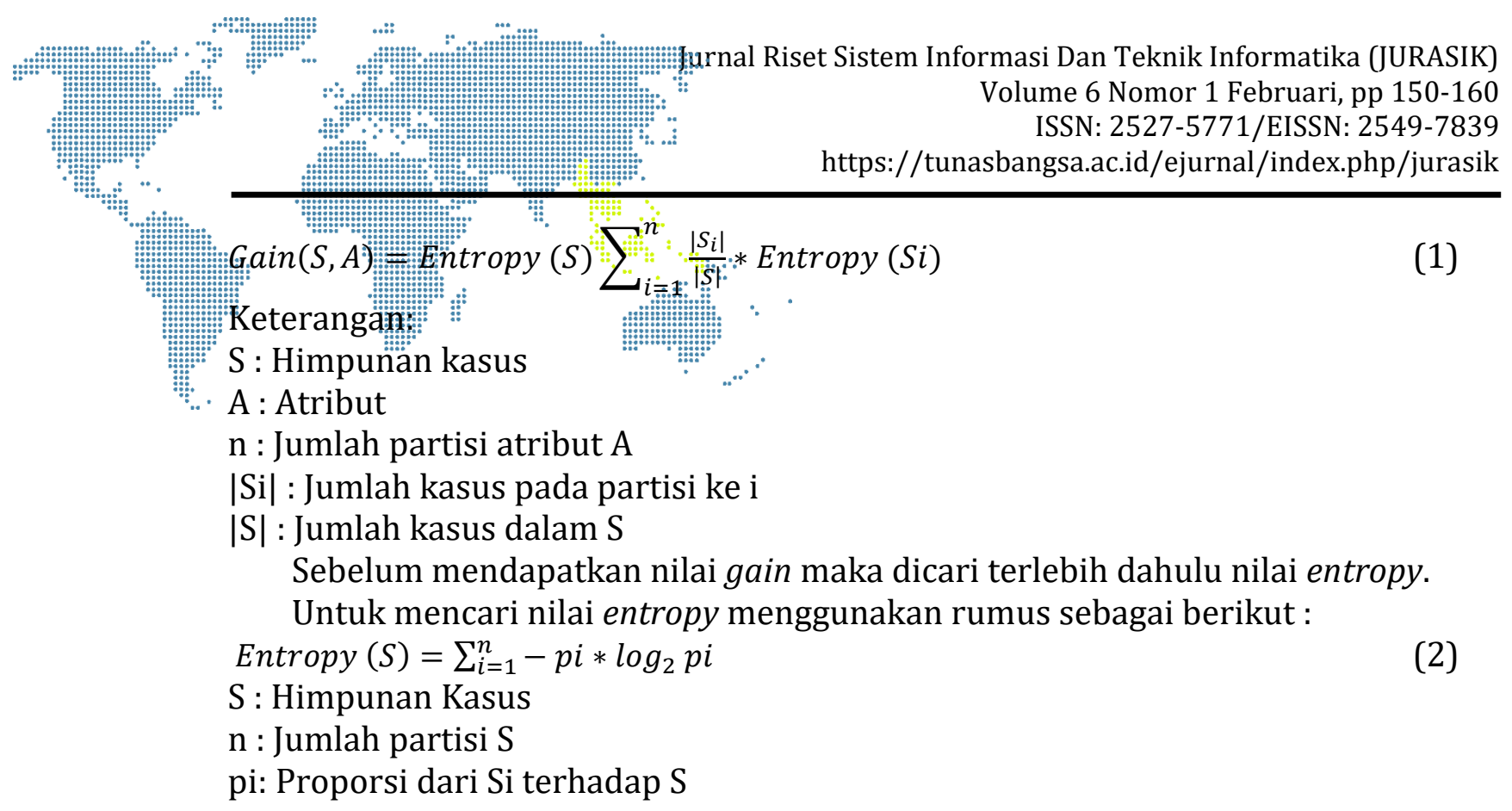

\section{c. RapidMiner}

RapidMiner adalah suatu perangkat lunak yang sifatnya terbuka (open source). RapidMiner juga merupakan solusi untuk melakukan analisis prediksi yang menggunakan berbagai macam teknik deksriptif dan prediksi untuk memberikan suatu wawasan kepada penggunanya, sehingga menghasilkan sebuah keputusan yang sangat baik [6].

\section{HASIL DAN PEMBAHASAN}

\subsection{Perhitungan Menggunakan Algoritma C4.5}

Perhitungan Algoritma C4.5 dimulai dengan memilih atribut akar terlebih dahulu dengan mencari jumlah kasus keseluruhan, jumlah kasus keputusan puas dan jumlah kasus keputusan tidak puas. Menghitung Entrophy dari semua kasus yang dibagi berdasarkan Usia, Pekerjaan, Lama menjadi nasabah, Assurance, Tangible dan Responsiveness. Setelah itu dilakukan perhitungan Gain untuk masing-masing atribut. Hasil perhitungan ditunjukkan oleh tabel berikut ini :

Tabel 2. Perhitungan Node 1

\begin{tabular}{|c|c|c|c|c|c|}
\hline \multirow[t]{2}{*}{ Total } & Jumlah & Puas & $\begin{array}{l}\text { Tidak } \\
\text { Puas } \\
\end{array}$ & Entrophy & \multirow[t]{2}{*}{ Gain } \\
\hline & 50 & 37 & 13 & 0,826746372 & \\
\hline \multicolumn{5}{|l|}{ Umur } & 0,00447401 \\
\hline Remaja & 10 & 9 & 1 & 0,468995594 & \\
\hline Dewasa & 28 & 19 & 8 & 0,895998576 & \\
\hline Tua & 12 & 7 & 4 & 0,981925254 & \\
\hline \multicolumn{5}{|l|}{ Pekerjaan } & 0,018671265 \\
\hline \begin{tabular}{l|l} 
Pelajar \\
\end{tabular} & 12 & 9 & 3 & 0,811278124 & \\
\hline Pegawai BUMN & 8 & 7 & 1 & 0,543564443 & \\
\hline Wiraswasta & 10 & 7 & 3 & 0,881290899 & \\
\hline PNS & 10 & 8 & 2 & 0,721928095 & \\
\hline Pegawai Swasta & 10 & 5 & 4 & 1,028771238 & \\
\hline \multicolumn{5}{|l|}{ Lama Menjadi Nasabah } & 0,02362563 \\
\hline \begin{tabular}{l|l} 
& $\mathrm{L}$ \\
\end{tabular} & 18 & 13 & 5 & 0,852405179 & \\
\hline $\mathrm{BR}$ & 18 & 12 & 6 & 0,918295834 & \\
\hline $\mathrm{CL}$ & 14 & 12 & 2 & 0,591672779 & \\
\hline
\end{tabular}




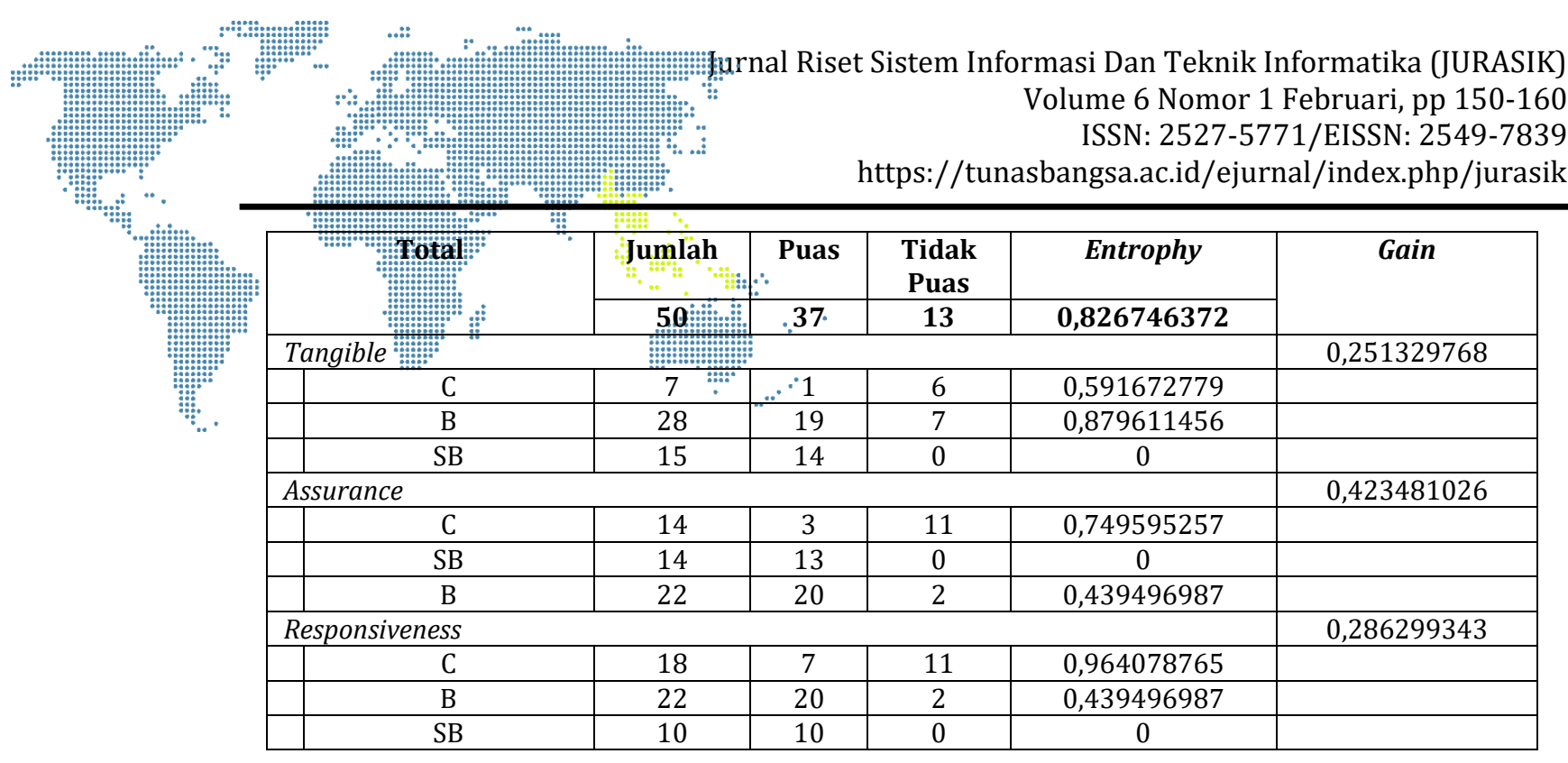

Kolom nilai Entrophy pada baris total dihitung dengan persamaan (1) sebagai berikut :

Entrophy (total) $=-(13 / 50) *$ LOG2(13/50) $-(37 / 50) *$ LOG2(37/50)

Entrophy (total) $=0,826746372$ berikut :

Kemudian pada nilai Gain pada baris Umur dihitung persamaan (2) sebagai

Gain (total,Umur) $=(0,826746372)-((10 / 50) * 0,468995594+(28 / 50) *$

$0,895998576+$

$(12 / 50) * 0,981925254)$

Gain (total,Umur) = -0,00447401

Dari hasil perhitungan pada tabel 4.1 diperoleh atribut yang menjadi Node (akar) adalah Assurance memiliki Gain tertinggi yaitu 0,423481026, dimana terdiri dari 3 sub atribut yaitu C, B, dan SB. Berdasarkan nilai Entrophy dari ketiga sub atribut diatas, sub atribut SB yang memperoleh keputusan. Sedangkan untuk sub atribut $\mathrm{C}$ dan $\mathrm{B}$ belum memperoleh keputusan maka perlu dilakukan perhitungan lebih lanjut untuk menentukan Node akar selanjutnya,dapat digambarkan pohon keputusan dari tabel diatas sebagai berikut:

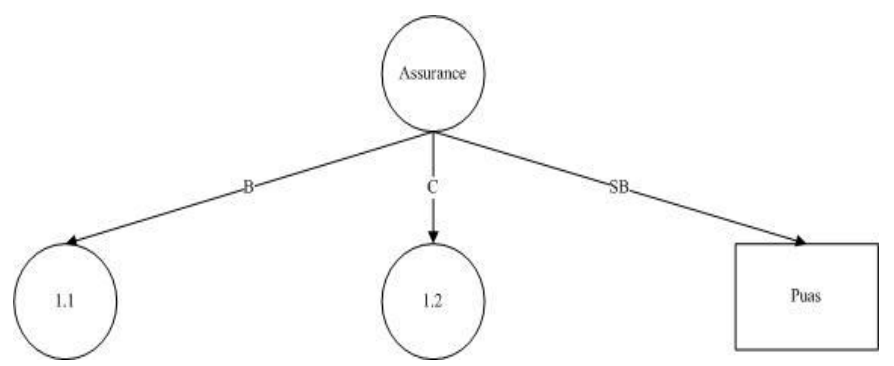

Gambar 1. Pohon Keputusan 1

Untuk hasil perhitungan selanjutnya Algoritma C4.5 dapat ditunjukkan pada tabel berikut ini :

Tabel 3. Perhitungan Node 1.1

\begin{tabular}{|l|c|c|c|c|c|}
\hline & Jumlah & Puas & Tidak Puas & Entrophy & Gain \\
\hline Asurance $=$ B & 22 & 20 & 2 & 0,439496987 & \\
\hline
\end{tabular}




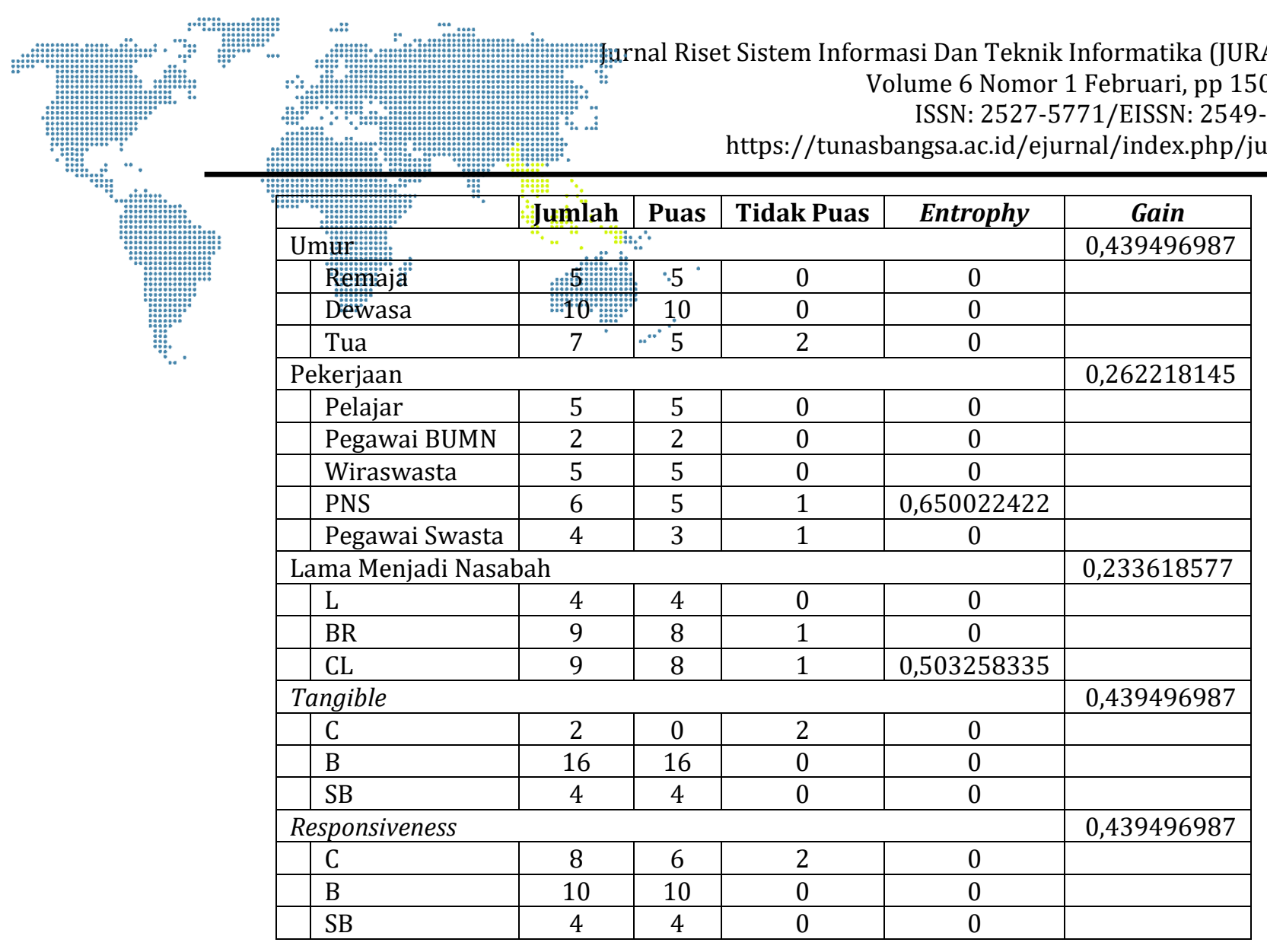

Dari hasil perhitungan diatas pada tabel 4.2, atribut yang menjadi Node cabang dari atribut Assurance-B adalah Tangible. Dimana atribut dari Tangible sudah memperoleh keputusan. Maka dapat digambarkan pohon keputusan dari tabel diatas sebagai berikut :

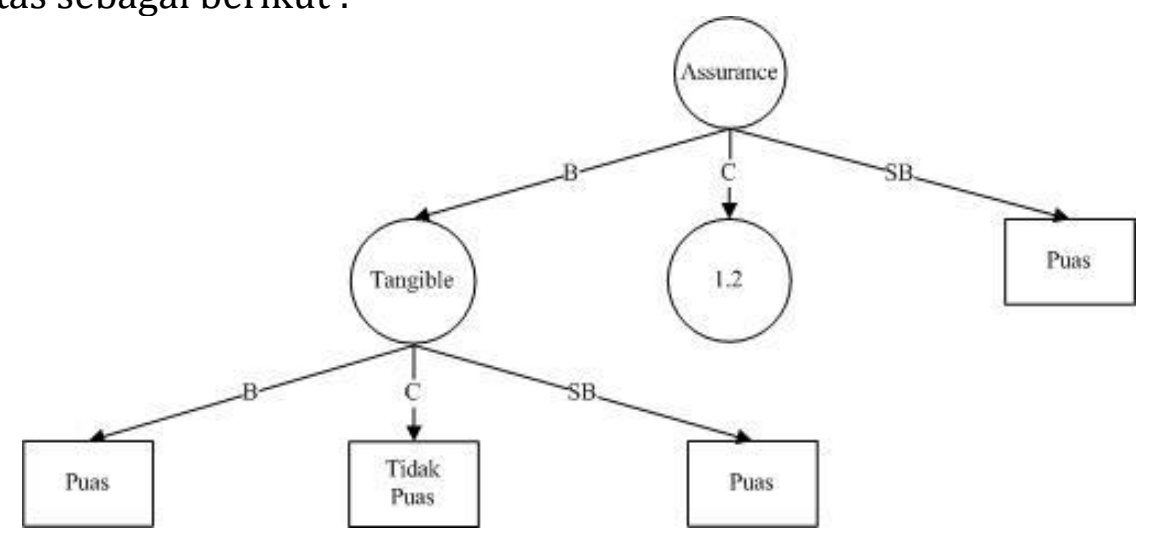

Gambar 2. Pohon Keputusan 2

Dalam mencari hasil perhitungan selanjutnya pada Node akar Asurance-C dapat ditunjukkan pada tabel berikut ini :

Tabel 4. Perhitungan Node 1.2.

\begin{tabular}{lccccc}
\hline Asurance $=$ C & Jumlah & Puas & Tidak Puas & Entrophy & Gain \\
& 14 & 3 & 11 & 0,749595257 & \\
\hline Umur & & & & & 0,08539095
\end{tabular}




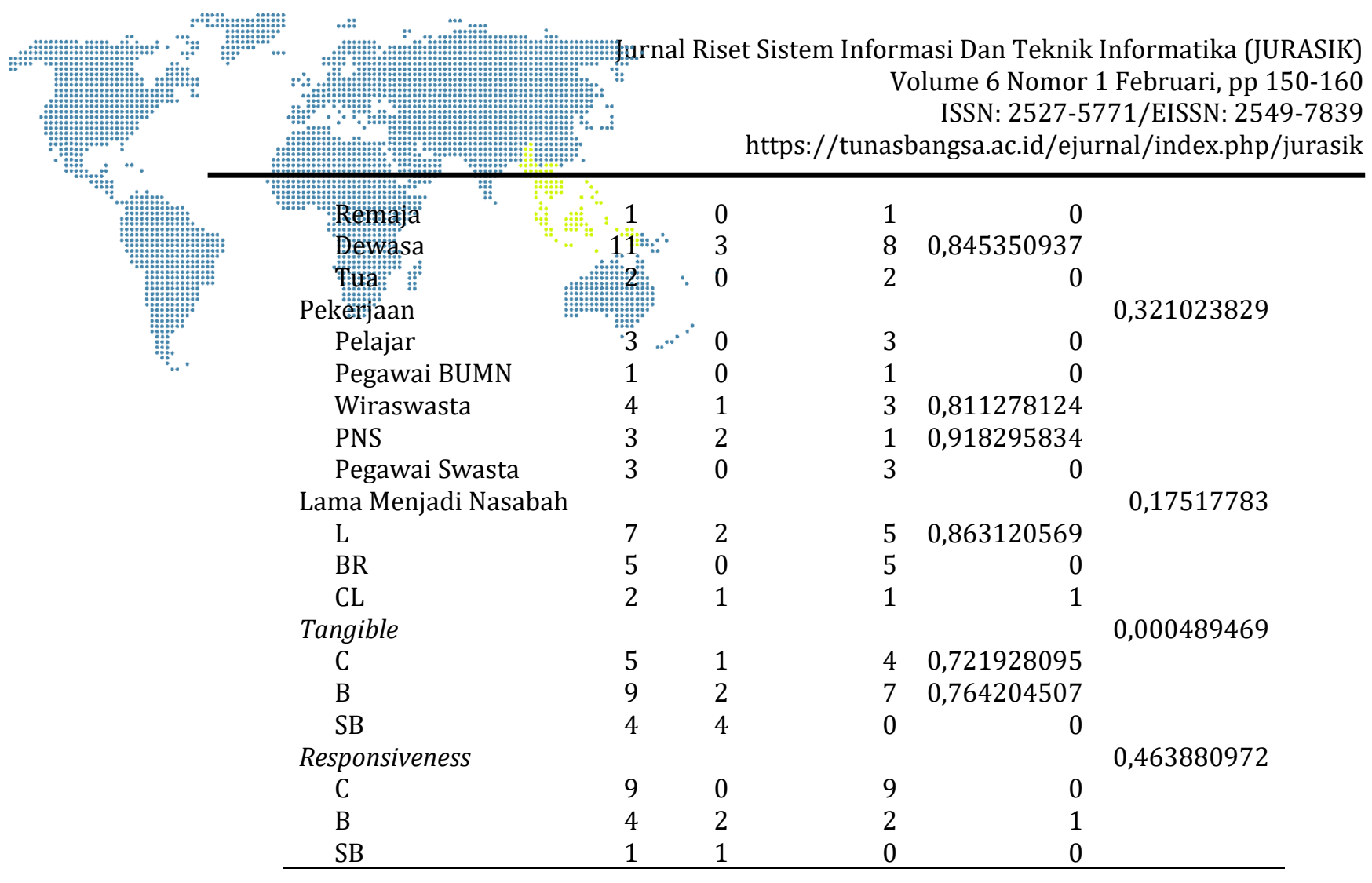

Dari hasil perhitungan pada tabel 4.3, atribut yang menjadi Node cabang dari Assurance-C adalah Responsiveness. Dimana sub atribut C dan SB sudah menghasilkan keputusan sedangkan sub atribut B belum menghasilkan keputusan, sehingga perhitungan dilanjutkan kembali. Maka dapat digambarkan pohon keputusan dari tabel diatas sebagai berikut :

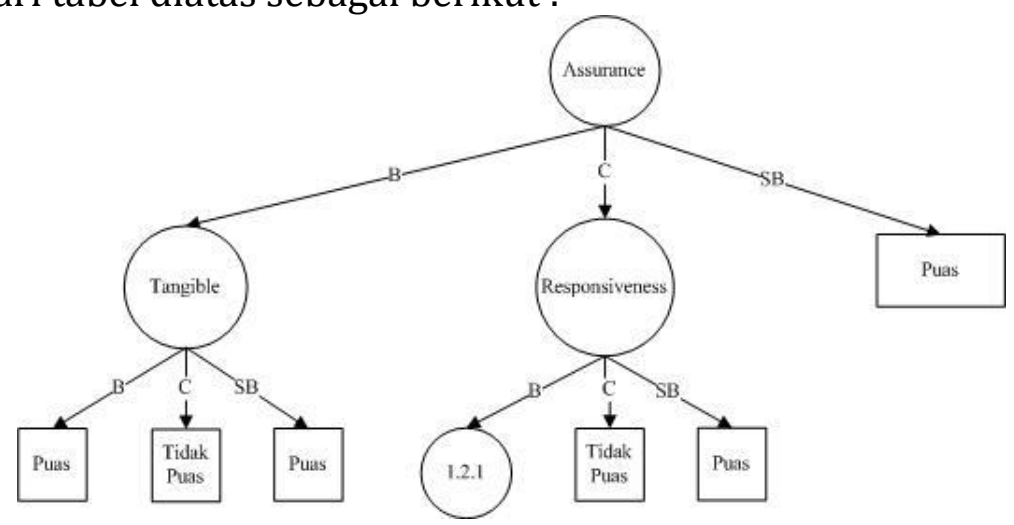

Gambar 3. Pohon Keputusan 3

Selanjutnya melakukan perhitungan pada Node cabang dari atribut Assurance-C dan Responsive-B dapat ditunjukan pada tabel 5.

Tabel 5. Perhitungan Node 1.2.1

\begin{tabular}{|c|c|c|c|c|c|}
\hline \multirow[t]{2}{*}{ Asurance $=\underset{\text { B }}{\text { C dan }}$ Responsive $=$} & Jumlah & Puas & $\begin{array}{l}\text { Tidak } \\
\text { Puas }\end{array}$ & Entrophy & Gain \\
\hline & 4 & 2 & 2 & 1 & \\
\hline \multicolumn{5}{|l|}{ Umur } & 0 \\
\hline \begin{tabular}{l|l} 
Remaja &
\end{tabular} & 0 & 0 & 0 & 0 & \\
\hline Dewasa & 4 & 2 & 2 & 1 & \\
\hline
\end{tabular}




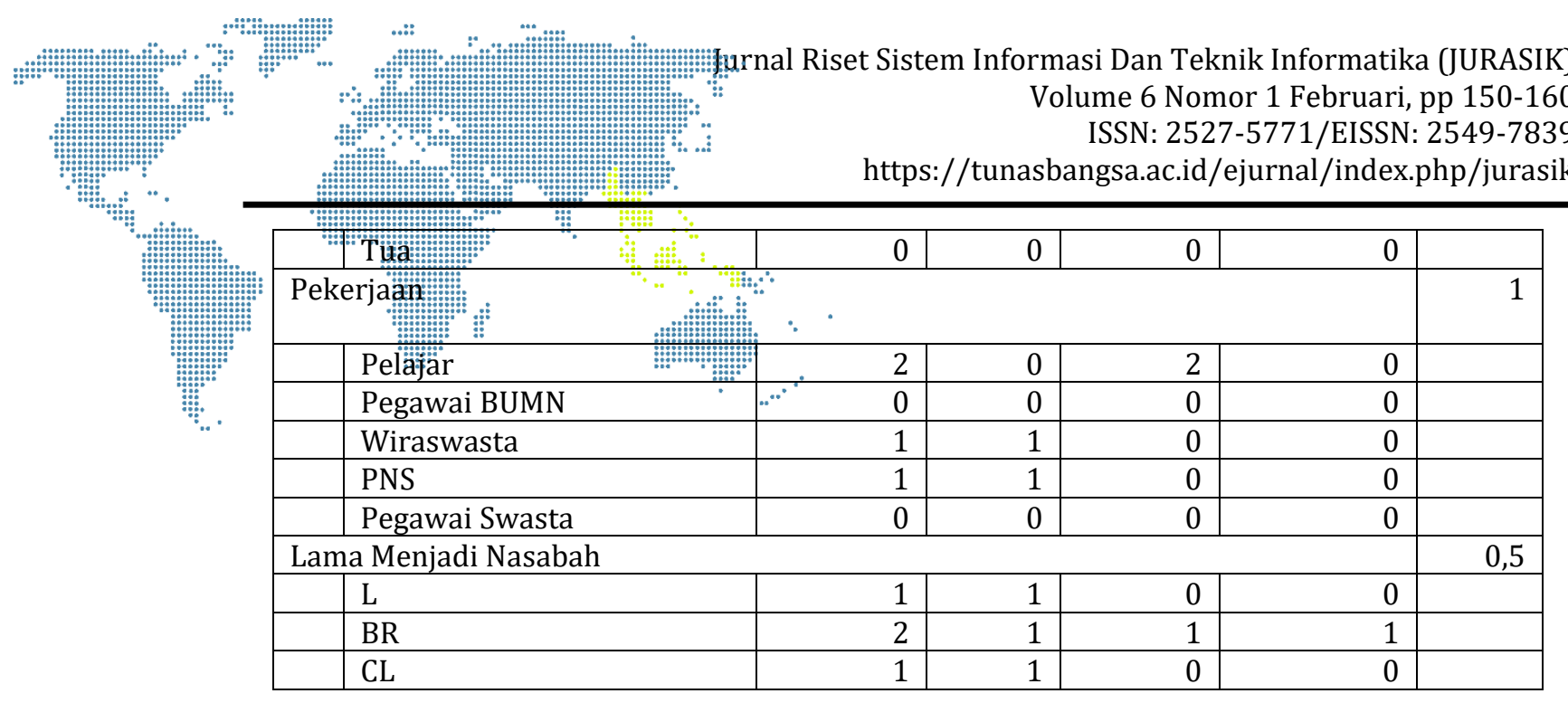

Dari hasil perhitungan diatas pada tabel 5, atribut yang menjadi Node cabang dari atribut Assurance-C Responsive-B adalah pekerjaan. Dimana atribut dari pekerjaan yang terdiri dari Pelajar, Pegawai BUMN, Wiraswasta, PNS dan Pegawai Swasta. Dimana seluruh sub atribut sudah memperoleh keputusan, sehingga perhitungan selesai. Maka dapat digambarkan pohon keputusan dari tabel diatas sebagai berikut :

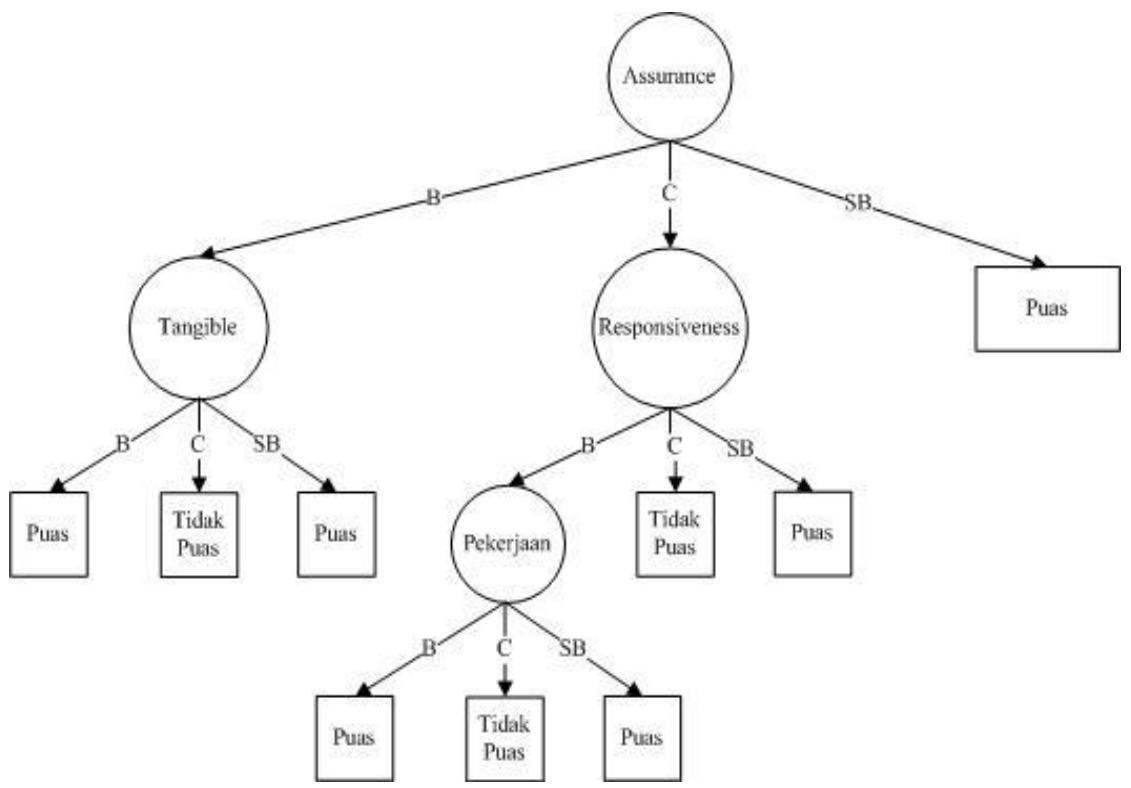

Gambar 4. Pohon Keputusan 4

\subsection{Pembahasan}

Setelah dilakukan perhitungan dan pengujian data pada masing-masing atribut dengan Algoritma C4.5, maka akan didapatkan pola pohon keputusan akhir. 


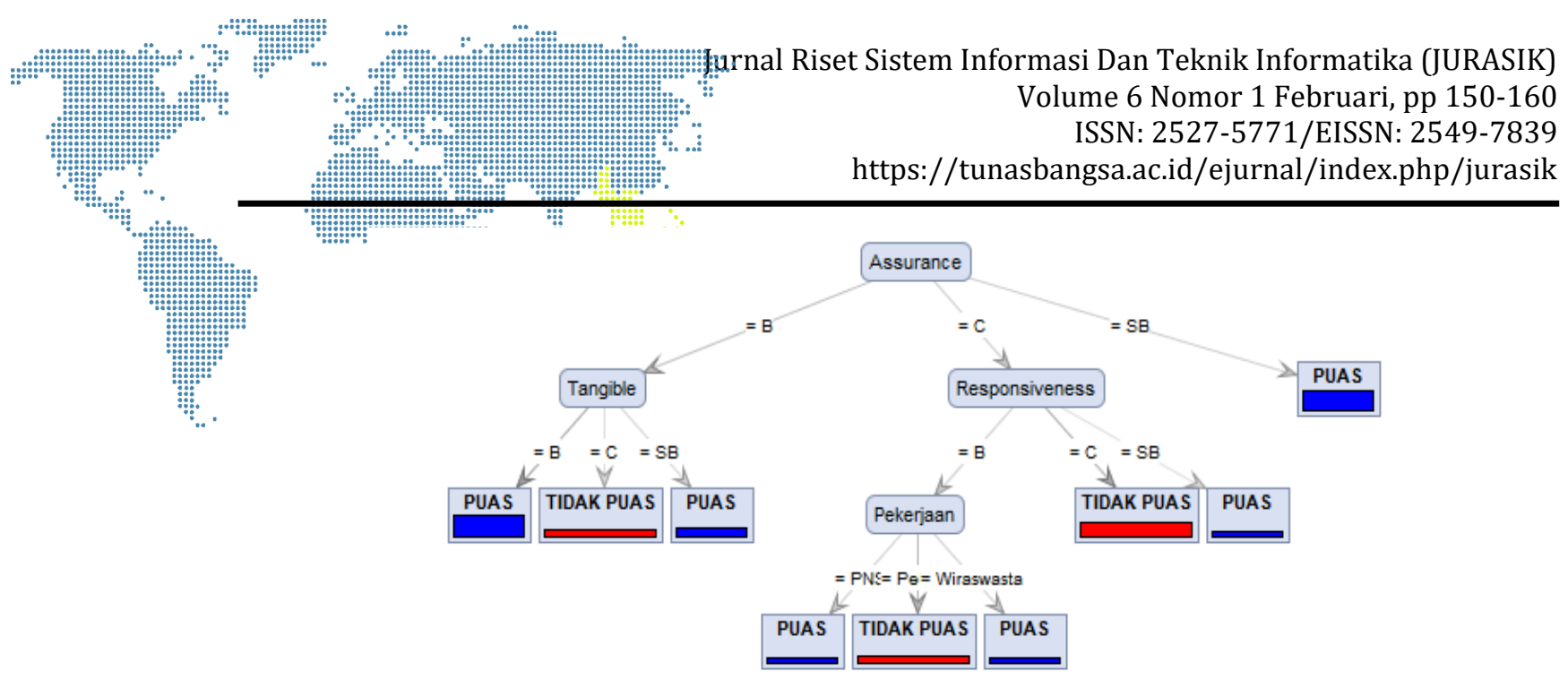

Gambar 5. Hasil Decision Tree

Tampilan Deskripsi Decision Tree

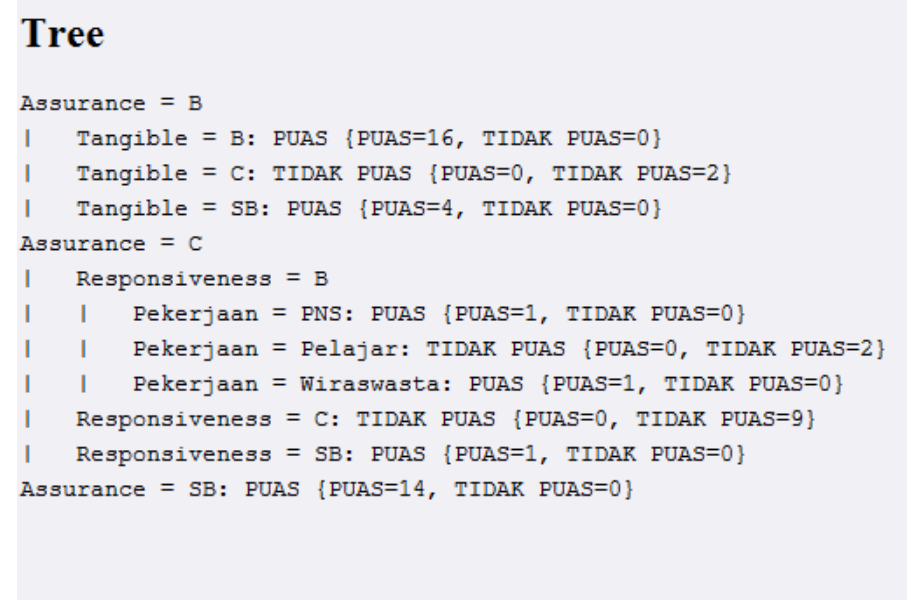

Gambar 6. Deskripsi Decision Tree

Gambar di atas menunjukkan hasil deskripsi secara lengkap dari pohon keputusan (Decision Tree) yang telah terbentuk dengan menggunakan Algoritma C4.5. Dari hasil deskripsi juga menunjukkan bahwa penggunaan Data Mining Algoritma C4.5 baik digunakan dalam proses menggali data (Data Mining Process) untuk menarik beberapa kesimpulan yang divisualisasikan dengan pohon keputusan (Decision Tree). Berikut ini Rules yang dihasilkan dari pohon keputusan tersebut:

Tabel 6. Rule yang dihasilkan

\begin{tabular}{|l|l|l|}
\hline No & \multicolumn{1}{|c|}{ Rules } & \multicolumn{1}{|c|}{ Keputusan } \\
\hline 1. & Jika Assurance $=$ B dan Tangible $=$ B & Puas \\
\hline 2. & Jika Assurance $=$ B dan Tangible $=$ C & Tidak Puas \\
\hline 3. & Jika Assurance $=$ B dan Tangible $=$ SB & Puas \\
\hline 4. & $\begin{array}{l}\text { Jika Assurance }=\text { C dan Responsive }=\text { B dan Pekerjaan }= \\
\text { PNS }\end{array}$ & Puas \\
\hline 5. & $\begin{array}{l}\text { Jika Assurance }=\text { C dan Responsive }=\text { B dan Pekerjaan }= \\
\text { Pelajar }\end{array}$ & Tidak Puas \\
\hline
\end{tabular}




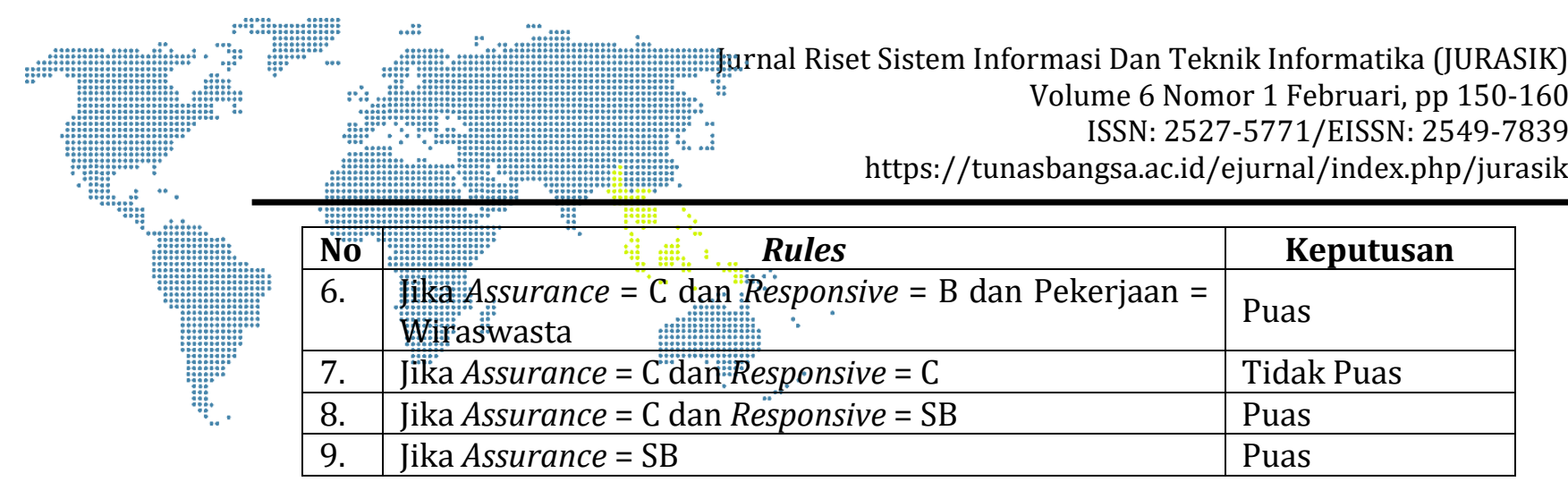

Tingkat Akurasi

\begin{tabular}{|c|c|c|c|}
\hline \multicolumn{3}{|c|}{ (2) Multiclass Classification Performance $\bigcirc$ Annotations } & \multirow[t]{2}{*}{ 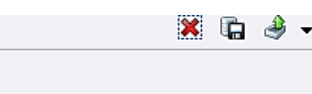 } \\
\hline \multicolumn{3}{|c|}{ (-) Table View $\bigcirc$ Plot View } & \\
\hline \multicolumn{4}{|l|}{ accuracy: $93.33 \%$} \\
\hline & true PUAS & true TIDAK PUAS & class precision \\
\hline pred. PUAS & 9 & 1 & $90.00 \%$ \\
\hline pred. TIDAK PUAS & 0 & 5 & $100.00 \%$ \\
\hline class recall & $100.00 \%$ & $83.33 \%$ & \\
\hline
\end{tabular}

Gambar 7. Nilai Akurasi Algoritma C4.5

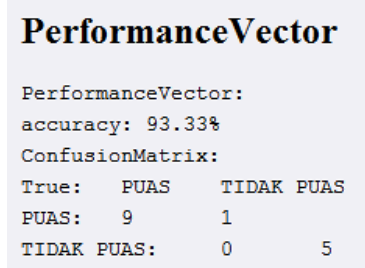

Gambar 8. Nilai Performance Vector Algoritma C4.5

Berdasarkan pengolahan data menggunakan Software RapidMiner didapat nilai akurasi sistem sebesar 90,00\%, artinya bahwa Rule yang dihasilkan tingkat kebenaran mendekati 100\%. Dimana model yang telah dibentuk diuji tingkat akurasinya dengan memasukan atau uji yang berasal dari data Training dengan menggunakan Split Validation pada aplikasi RapidMiner 5.3 untuk menguji tingkat akurasi.

\section{SIMPULAN}

Berdasarkan seluruh hasil tahapan penelitian yang telah dilakukan pada Penerapan Algoritma C4.5 dalam mengklasifikasi pada kualitas pelayanan terhadap nasabah pada Bank Syariah Mandiri dapat disimpulkan sebagai berikut.

a) Permasalahan menentukan kualitas pelayanan puas dan tidak puas dapat diselesaikan menggunakan teknik Data Mining, yaitu dengan Algoritma C4.5. Menghasilkan 9 (Sembilan) Rules dan tingkat akurasi yang dihasilkan oleh metode tersebut adalah 90,00\%.

b) Dengan adanya penerapan Data Mining Algoritma C4.5 diharapkan mampu memberikan solusi kepada pihak Bank Syariah Mandiri dalam 


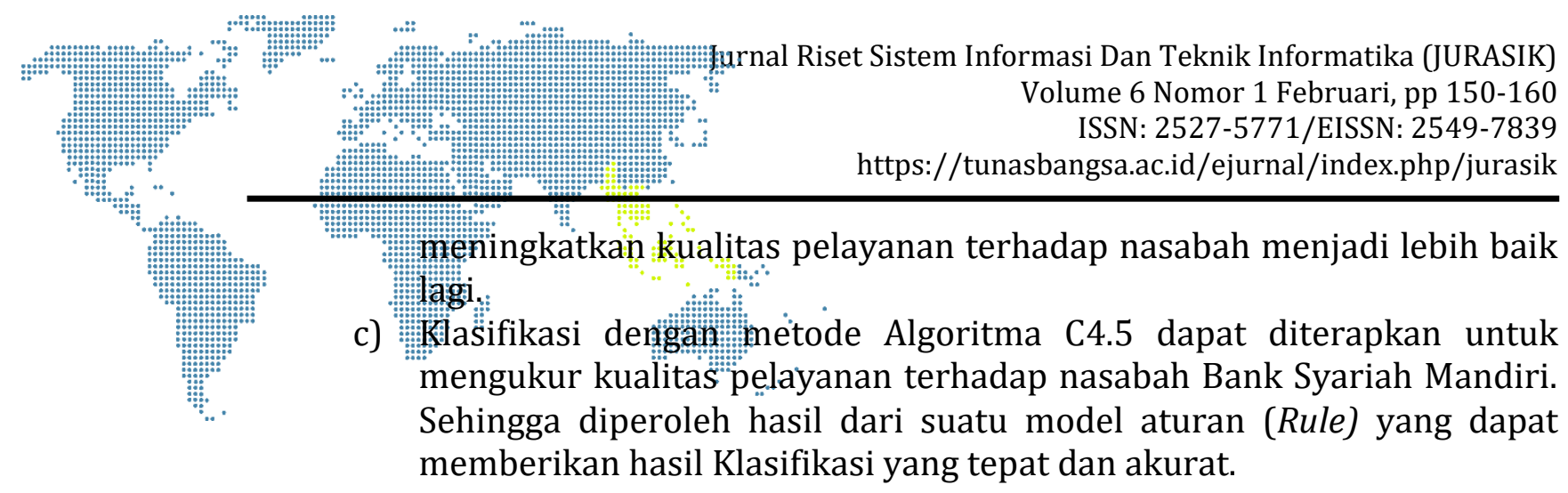

\section{DAFTAR PUSTAKA}

[1] D. Ardiansyah And W. Walim, "Algoritma C4.5 Untuk Klasifikasi Calon Peserta Lomba Cerdas Cermat Siswa Smp Dengan Menggunakan Aplikasi Rapid Miner," J. Inkofar, Vol. 1, No. 2, Pp. 5-12, 2018.

[2] A. Maulana And A. A. Fajrin, "Penerapan Data Mining Untuk Analisis Pola Pembelian Konsumen Dengan Algoritma Fp-Growth Pada Data Transaksi Penjualan Spare Part Motor," Klik - Kumpul. J. Ilmu Komput., Vol. 5, No. 1, P. 27, 2018, Doi: 10.20527/Klik.V5i1.100.

[3] E. Elisa, "Analisa Dan Penerapan Algoritma C4.5 Dalam Data Mining Untuk Mengidentifikasi Faktor-Faktor Penyebab Kecelakaan Kerja Kontruksi Pt.Arupadhatu Adisesanti," J. Online Inform., Vol. 2, No. 1, P. 36, 2017, Doi: 10.15575/Join.V2i1.71.

[4] W. D. Septiani, "Komparasi Metode Klasifikasi Data Mining Algoritma C4.5 Dan Naive Bayes Untuk Prediksi Penyakit Hepatitis," J. Pilar Nusa Mandiri Vol., Vol. 13, No. 1, Pp. 76-84, 2017.

[5] A. S. Febriarini And E. Z. Astuti, "Penerapan Algoritma C4 . 5 Untuk Prediksi Kepuasan Penumpang Bus Rapid Transit ( Brt ) Trans Semarang," Pp. 95-103, 2019, Doi: 10.30864/Eksplora.V8i2.156.

[6] D. N. Batubara And A. P. Windarto, "Analisa Klasifikasi Data Mining Pada Tingkat Kepuasan Pengunjung Taman Hewan Pematang Siantar Dengan Algoritma," Komik (Konferensi Nas. Teknol. Inf. Dan Komputer), Vol. 3, No. 1, Pp. 588-592, 2019, Doi: 10.30865/Komik.V3i1.1664. 